\title{
Correspondence:
}

\section{Gastrointestinal involvement of COVID-19 and potential faecal transmission of SARS-CoV-2*}

\author{
Min $\mathrm{SONG}^{\S 1}$, Zong-lin $\mathrm{LI}^{\S 2}$, Ye-jiang $\mathrm{ZHOU}^{2}$, \\ Gang TIAN ${ }^{1}$, Ting $\mathrm{YE}^{1}$, Zhang-rui ZENG ${ }^{1}$, \\ Jian DENG ${ }^{1}$, Hong WAN ${ }^{1}$, Qing $\mathrm{LI}^{1}$, Jin-bo LIU ${ }^{\dagger 11}$ \\ ${ }^{1}$ Department of Laboratory Medicine, the Affiliated Hospital of \\ Southwest Medical University, Luzhou 646000, China \\ ${ }^{2}$ Department of Gastrointestinal Surgery, the Affiliated Hospital of \\ Southwest Medical University, Luzhou 646000, China \\ †E-mail: liujb7203@163.com
}

https://doi.org/10.1631/jzus.B2000253

Coronavirus disease 2019 (COVID-19), caused by the severe acute respiratory syndrome coronavirus 2 (SARS-CoV-2), was found initially in Wuhan, China in early December 2019. The pandemic has spread to 216 countries and regions, infecting more than 23310000 people and causing over 800000 deaths globally by Aug. 24, 2020, according to World Health Organization (https://www.who.int/emergencies/diseases/ novel-coronavirus-2019). Fever, cough, and dyspnea are the three common symptoms of the condition, whereas the conventional transmission route for SARS-CoV-2 is through droplets entering the respiratory tract. To date, infection control measures for COVID-19 have been focusing on the involvement of the respiratory system. However, ignoring potential faecal transmission and the gastrointestinal involvement of SARS-CoV-2 may result in mistakes in attempts to control the pandemic.

\footnotetext{
"Corresponding author

$\S$ The two authors contributed equally to this work

* Project supported by the Key Research and Development of Science and Technology Projects of Luzhou (Special Project Fund for Emergency Research), China

(D) ORCID: Min SONG, https://orcid.org/0000-0002-4260-6268; Jin-bo LIU, https://orcid.org/0000-0001-9042-2829

(C) Zhejiang University and Springer-Verlag GmbH Germany, part of Springer Nature 2020
}

The SARS epidemic broke out in 2003, while the Middle East respiratory syndrome (MERS) appeared in 2012 , both characterized by fever and respiratory tract infection. Nonetheless, many SARS and MERS patients complained of gastrointestinal symptoms such as diarrhea, vomiting, and abdominal pain (Peiris et al., 2003; Nassar et al., 2018). It was reported that angiotensin-converting enzyme 2 (ACE2) and dipeptidyl peptidase 4 (DPP4) were the functional receptors for the SARS-CoV and the MERS coronavirus (MERS-CoV), respectively, both highly expressed in intestinal epithelial cells (Li et al., 2003; Raj et al., 2013). Not only active viral replication within intestine was confirmed by research, but also SARS-CoV was isolated from intestinal specimens of SARS patients (Leung et al., 2003). Zhou et al. (2017) demonstrated that MERS-CoV could reproduce easily in the small intestine, and that pulmonary infection by MERS-CoV in human DPP4 (hDPP4) mice was secondary to intestinal infection. Clearly, SARS-CoV and MERS-CoV were shown to easily infect intestinal cells, and thus faecal transmission of these viruses seemed very likely.

Considering a genome sequence homology of $79 \%$ or $50 \%$ between SARS-CoV-2 and SARS-CoV or MERS-CoV, respectively, SARS-CoV-2 routinely causes respiratory infection, but it can also target the gastrointestinal system ( $\mathrm{Lu}$ et al., 2020). A multicenter clinical dataset revealed that COVID-19 patients presenting gastrointestinal symptoms (diarrhea, nausea, or vomiting) accounted for $11.37 \%$ (74/651), with diarrhea being the most common symptom accounting for $8.14 \%(53 / 651)$ of all cases. Among the 74 patients with gastrointestinal symptoms, 21 only had gastrointestinal but no respiratory symptoms throughout the course of COVID-19, making up less than a third $(28.38 \%)$ of patients $(21 / 74)$. More importantly, the abundance of the more severe illness 
type was much higher in patients with gastrointestinal symptoms than those without such symptoms (22.97\% vs. $8.14 \%, P<0.001)$ (Jin et al., 2020). The enzymes ACE2 and transmembrane serine protease 2 (TMPRSS2) have been proven to be cell receptors for SARS-CoV-2, and are abundantly expressed in gastrointestinal cells supporting gastrointestinal infection by SARS-CoV-2 (Lee et al., 2020; Xiao et al., 2020). The RNA of SARS-CoV-2 was detected in the faecal sample in $55.41 \%$ (41/74) of all COVID-19 patients. In addition, tests for SARS-CoV-2 RNA in faecal samples remained positive for a mean of $27.9 \mathrm{~d}$, which was much longer than that for respiratory samples with a mean of $11.2 \mathrm{~d}$, while this test was positive for a continuous $33.0 \mathrm{~d}$ in one patient after respiratory samples became negative ( $\mathrm{Wu}$ et al., 2020). It has been established that intestinal epithelium supports SARS-CoV-2 replication, and human small intestinal organoids can serve as an experimental model for SARS-CoV-2 infection (Lamers et al., 2020). Accordingly, live SARS-CoV-2 was detected in faecal samples from two patients, both without gastrointestinal symptoms (Wang et al., 2020). Consequently, the gastrointestinal tract is an optimal target for infection by and the spread of SARS-CoV-2.

Regrettably, the COVID-19 outbreak is still ongoing, and the pandemic is becoming increasingly serious with a rapid growth of confirmed disease and death cases. This increasing severity of the pandemic necessitates the enhancement and perfection of current prevention and control measures. Until now, respiratory symptoms and fever are overemphasized, while some non-classical symptoms such as diarrhea have been overlooked, posing an enormous threat to the public. Based on evidence that live SARS-CoV-2 exists in faeces, and viral shedding from the gastrointestinal tract takes longer than that from the respiratory tract, we believe that SARS-CoV-2 can spread easily via faeces. Currently, there are no relevant reports on the faecal occurrence of SARS-CoV-2; however, we speculate that the virus may be derived from the respiratory tract via swallowing or directly from gastrointestinal cells infected by SARS-CoV-2 (Fig. 1). The latest experimental research has revealed that SARS-CoV-2, the stability of which was similar to SARS-CoV under experimental circumstances, could remain viable and infectious for over $3 \mathrm{~h}$ in aerosols and $72 \mathrm{~h}$ on the surface of plastic or stainless steel (van Doremalen et al., 2020). The aerodynamic nature of SARS-CoV-2 was investigated by measuring viral RNA in aerosols in different areas of two hospitals, with results confirming that the highest concentration of SARS-CoV-2 RNA in aerosols occurred in the patients' toilet room $\left(19\right.$ copies $\left./ \mathrm{m}^{3}\right)$ (Liu et al., 2020). Moreover, SARS-CoV-2 was identified in sewage in Italy (la Rosa et al., 2020). More importantly, the estimated number of COVID-19 cases based on the analysis of untreated wastewater was in reasonable agreement with clinical observations in Australia (Ahmed et al., 2020). All these findings suggest that people exposed to environments contaminated with faeces, such as public toilets or areas with poor sanitation, may be subject to "faecalaerosol-mucosal transmission" when virus particles touch their noses or eyes. Alternatively, water or food contaminated with faeces may be a source of "fecaloral transmission" (Fig. 1). Therefore, an effective management and disinfection of areas potentially contaminated with the faeces of COVID-19 patients is considered essential to control the COVID-19 pandemic.

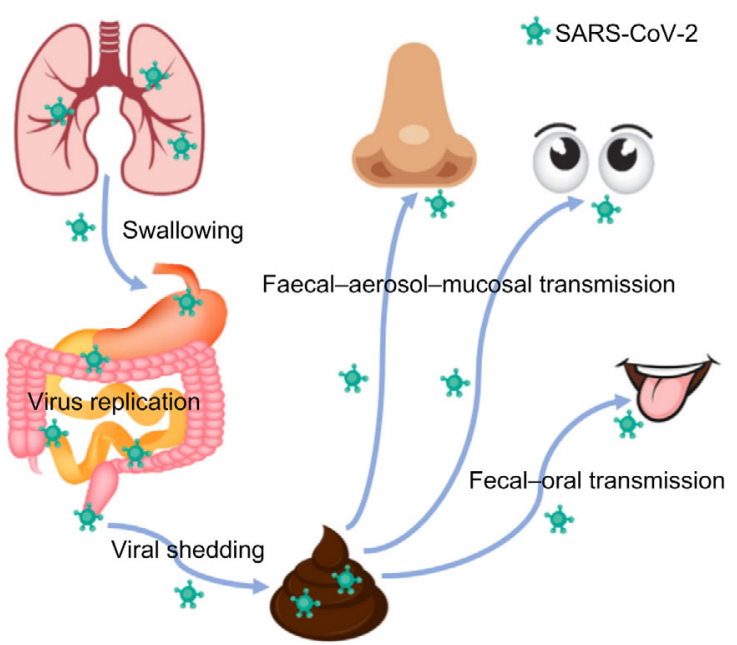

Fig. 1 Potential faecal transmission of SARS-CoV-2

\section{Contributors}

Jin-bo LIU, Min SONG, and Zong-lin LI devised the original idea for the comment. Min SONG, Zong-lin LI, and Ye-jiang ZHOU drafted the original manuscript. Gang TIAN, Ting YE, Zhang-rui Zeng, Jian DENG, Hong WAN, and Qing LI did the literature search and provided ideas for perfection. All authors critically reviewed the article and Jin-bo LIU gave the final approval for the version to be published. 


\section{Compliance with ethics guidelines}

Min SONG, Zong-lin LI, Ye-jiang ZHOU, Gang TIAN, Ting YE, Zhang-rui ZENG, Jian DENG, Hong WAN, Qing LI, and Jin-bo LIU declare that they have no conflict of interest.

This article does not contain any studies with human or animal subjects performed by any of the authors.

\section{References}

Ahmed W, Angel N, Edson J, et al., 2020. First confirmed detection of SARS-CoV-2 in untreated wastewater in Australia: a proof of concept for the wastewater surveillance of COVID-19 in the community. Sci Total Environ, 728:138764. https://doi.org/10.1016/j.scitotenv.2020.138764

Jin X, Lian JS, Hu JH, et al., 2020. Epidemiological, clinical and virological characteristics of 74 cases of coronavirusinfected disease 2019 (COVID-19) with gastrointestinal symptoms. Gut, 69(6):1002-1009. https://doi.org/10.1136/gutjnl-2020-320926

la Rosa G, Iaconelli M, Mancini P, et al., 2020. First detection of SARS-CoV-2 in untreated wastewaters in Italy. Sci Total Environ, 736:139652. https://doi.org/10.1016/j.scitotenv.2020.139652

Lamers MM, Beumer J, van der Vaart J, et al., 2020. SARS$\mathrm{CoV}-2$ productively infects human gut enterocytes. $\mathrm{Sci}$ ence, 369(6499):50-54. https://doi.org/10.1126/science.abc1669

Lee JJ, Kopetz S, Vilar E, et al., 2020. Relative abundance of SARS-CoV-2 entry genes in the enterocytes of the lower gastrointestinal tract. Genes (Basel), 11(6):645. https://doi.org/10.3390/genes11060645

Leung WK, To KF, Chan PKS, et al., 2003. Enteric involvement of severe acute respiratory syndrome-associated coronavirus infection. Gastroenterology, 125(4):1011-1017. https://doi.org/10.1016/j.gastro.2003.08.001

Li W, Moore MJ, Vasilieva N, et al., 2003. Angiotensinconverting enzyme 2 is a functional receptor for the SARS coronavirus. Nature, 426(6965):450-454. https://doi.org/10.1038/nature02145

Liu Y, Ning Z, Chen Y, et al., 2020. Aerodynamic analysis of SARS-CoV-2 in two Wuhan hospitals. Nature, 582(7813): 557-560. https://doi.org/10.1038/s41586-020-2271-3

Lu RJ, Zhao X, Li J, et al., 2020. Genomic characterisation and epidemiology of 2019 novel coronavirus: implications for virus origins and receptor binding. Lancet, 395(10224): 565-574. https://doi.org/10.1016/S0140-6736(20)30251-8

Nassar MS, Bakhrebah MA, Meo SA, et al., 2018. Middle East Respiratory Syndrome Coronavirus (MERS-CoV) infection: epidemiology, pathogenesis and clinical characteristics. Eur Rev Med Pharmacol Sci, 22(15):4956-4961. https://doi.org/10.26355/eurrev_201808_15635

Peiris JSM, Chu CM, Cheng VCC, et al., 2003. Clinical progression and viral load in a community outbreak of coronavirus-associated SARS pneumonia: a prospective study. Lancet, 361(9371):1767-1772.

https://doi.org/10.1016/s0140-6736(03)13412-5

Raj VS, Mou HH, Smits SL, et al., 2013. Dipeptidyl peptidase 4 is a functional receptor for the emerging human coronavirus-EMC. Nature, 495(7440):251-254.

https://doi.org/10.1038/nature12005

van Doremalen N, Bushmaker T, Morris DH, et al., 2020. Aerosol and surface stability of SARS-CoV-2 as compared with SARS-CoV-1. N Engl J Med, 382(16):15641567. https://doi.org/10.1056/NEJMc2004973

Wang WL, Xu YL, Gao RQ, et al., 2020. Detection of SARSCoV-2 in different types of clinical specimens. JAMA, 323(18):1843-1844. https://doi.org/10.1001/jama.2020.3786

$\mathrm{Wu}$ YJ, Guo C, Tang LT, et al., 2020. Prolonged presence of SARS-CoV-2 viral RNA in faecal samples. Lancet Gastroenterol Hepatol, 5(5):434-435. https://doi.org/10.1016/S2468-1253(20)30083-2

Xiao F, Tang MW, Zheng XB, et al., 2020. Evidence for gastrointestinal infection of SARS-CoV-2. Gastroenterology, 158(6):1831-1833.e3. https://doi.org/10.1053/j.gastro.2020.02.055

Zhou J, Li C, Zhao GY, et al., 2017. Human intestinal tract serves as an alternative infection route for Middle East respiratory syndrome coronavirus. $S c i A d v, 3(11)$ :eaao4966. https://doi.org/10.1126/sciadv.aao4966

\section{中文概要}

题 目: COVID-19 胃肠道感染和 SARS-CoV-2 潜在的粪 便传播

概 要: 多中心临床数据显示, 部分 2019 冠状病毒病 (COVID-19) 患者存在腹泻、恶心和呕吐等胃 肠道症状, 相关研究也证实严重急性呼吸综合征 冠状病毒 2 型 (SARS-CoV-2) 能够在胃肠道复 制并从粪便中分离到活的 SARS-CoV-2。在意大 利和澳大利亚等国, 其未处理的污水中检测到了 SARS-CoV-2, 且根据污水中 SARS-CoV-2 的含 量估算出的 COVID-19 患者与临床实际感染患者 较为一致。粪便中的 SARS-CoV-2 能够挥发存在 于气溶胶中并保持较长时间的活力, 故当人们暴 露在被 SARS-CoV-2 污染的环境中即可能经 “粪 便-气溶胶-粘膜” 途径感染 SARS-CoV-2, 而当 人们食用被 SARS-CoV-2 污染的食物或水则可能 经 “粪-口” 途径感染 SARS-CoV-2。因此, 对可 能被 COVID-19 患者粪便污染的环境或物品进行 严格管理和有效消毒对控制 COVID-19 大流行具 有重要意义。

关键词: 2019 冠状病毒病（COVID-19）; 严重急性呼吸 综合征冠状病毒 2 型（SARS-CoV-2）; 胃肠道 感染; 粪便传播 